\title{
Foreign direct investment flows: an analysis for Argentina, Brazil, Chile and Mexico based on the Grubel-Lloyd index
}

\author{
Álvaro Alves de Moura Junior, Pedro Raffy Vartanian \\ and Joaquim Carlos Racy
}

\section{Abstract}

This article assesses the importance of using the Grubel-Lloyd (GL) index as a tool to reveal trends in foreign direct investment (FDI). The index was developed to further the study of a fundamental question in international political economy: how FDI affects economies, whether individual or regional, and becomes a general framework indicator of regional behaviour. The index is applied to the four largest economies in Latin America (Argentina, Brazil, Chile and Mexico) in the period 1995-2016, with a view to demonstrating the importance of FDI for the region. However, the "behaviour" of FDI may be different for each country. The article discusses characteristics in each of these countries that differ from those found in the same indicator for a bloc consisting of the developed countries plus China, for which the index as calculated is higher and varies little during the period analysed.

\section{Keywords}

International economic relations, globalization, foreign direct investment, transnational corporations, measurement, Argentina, Brazil, Chile, Mexico

\section{JEL classification}

F20, F21, F23

\section{Authors}

Álvaro Alves de Moura Junior is professor and research fellow on the Postgraduate programme in Economics and Markets of Universidad Presbiteriana Mackenzie, Brazil. Email: alvaro.moura@mackenzie.br.

Pedro Raffy Vartanian is professor, coordinator and research fellow on the Postgraduate programme in Economics and Markets of Universidad Presbiteriana Mackenzie, Brazil. Email: pedro.vartanian@mackenzie.br.

Joaquim Carlos Racy is professor and research fellow on the Postgraduate programme in Economics and Markets of Universidad Presbiteriana Mackenzie, Brazil. Email: joaquimcarlos.racy@mackenzie.br. 


\section{Introduction}

Finance is considered the central link in the current stage of globalization, as well as the key determinant of many developments in other spheres of the international economic system. The expansion of international liquidity, especially since the 1990s, has fuelled a significant increase in flows of both portfolio capital and foreign direct investment (FDI).

According to Corazza (2005), these findings, which reflect financial globalization, result from three interrelated factors: (i) the high level of accumulation of monetary and financial wealth, held in the form of assets with different degrees of liquidity and traded in numerous currencies; (ii) the development of technological resources that make these assets extraordinarily mobile; and (iii) the current regime of floating exchange rates, which generates speculative gains.

In the case of FDI specifically, the corresponding increase in flows takes a very wide range of forms, including the following: the expansion of trade relations; flows of loans and financing between firms; the sale of technology; and the transfer of assets through mergers and acquisitions.

In reference to empirical evidence on the accuracy of FDI flows, there is an important caveat regarding the nature of this capital in relation to the classification of multinational firms, which Michalet (1985) defines as follows:

A firm (or a group), generally of large size, which, starting from a domestic base, has set up several branches abroad in several countries, following a strategy and an organization conceived on a global scale. This definition remains useful in several respects; it points out that the multinational enterprise invariably began as a large firm at the national level, which also means that it is the result of a more or less lengthy and complex process of concentration and centralization of capital, and that it often diversified before it began to internationalize; that the multinational firm has a national origin, so that the strengths and weaknesses of its national base and the assistance it has received from its State will be components of its strategy and its competitiveness; whereas this firm is generally a group whose contemporary legal form is that of an international holding company; and, lastly, that this group acts on a global scale and has strategies and an organization set up for this purpose (cited in Chesnais, 1996, p. 73).

In general, this discussion shows that the functional integration of multinational firms has become a fundamental characteristic of the current international economic scenario, which is increasingly based on a production chain that interconnects a sequence of operational functions, each of which adds value to the process of producing goods and services.

The production chains created by multinational firms have the capacity to coordinate and control operations in more than one country. To this end they develop increasingly sophisticated mechanisms of intra- and inter-organizational relations, which shape the contours of today's economic system.

As the activity of multinational firms involves decisions on exporting or internalizing the production process, it should also be recognized that this current movement is supported by different forms of coordination. These represent genuine networks of relations within and between firms, since the hierarchy of the economic system is structured on the basis of different degrees of power and influence. Consequently, these networks are considered dynamic and in a continuous state of mutation.

However, investment decisions, as expressed in recent trends in FDI flows, show that national borders remain relevant in terms of global economic policy, as they are one of the main determinants of firms' location choices - with a direct influence on FDI flows.

Consequently, States have increasingly sought to act in the international system with the aim of influencing the multinational firms' geographical choices. Among the main expressions of this process 
are the conditions offered to multinational firms in terms of access to the domestic market and to factors of production.

Another important point related to the performance of multinational firms is the actual process of setting up branches abroad, which, as has been noted before, usually occurs for the following reasons: (i) the chance to exploit raw materials located in the destination country; (ii) entry into the domestic market, which enables import substitution; and (iii) turning the destination country into a platform for exporting intermediate or finished products.

An analysis of the stock of FDI in 2016 shows that $63.3 \%$ of the capital in question was channelled to developed countries (UNCTAD, 2020). Nonetheless, there is no denying an effort to create a global market, in which the developing countries, as a bloc, absorbed $34 \%$ of the total stock of FDI in the same period.

When measured in terms of inflows, the United States is the main recipient of FDI, accounting for $23.9 \%$ of the total stock, while Latin America has a $7.3 \%$ share; hence the choice of countries analysed in this study.

In terms of outflows, developed countries accounted for $76.3 \%$ of the FDI stock in 2016, with developing countries representing 22.2\%, and the Latin American countries 2.2\%.

The networks of relationships that exist between domestic and multinational firms are usually denser and more extensive in developed economies than in developing ones. Moreover, in the latter, these linkages tend to occur in the larger, more industrialized economies. However, the majority of FDI flows are allocated to just a handful of developing countries, in particular the newly industrialized countries (NICs), ${ }^{1}$ and especially China. In this group, just nine countries accounted for $53.1 \%$ of the total FDI stock held in developing countries in 2012. Some of those countries are analysed in this research, not only from the FDI standpoint. An assessment is also made of the export of investment capital to other countries, as well as the relationships between these flows revealed through an indicator that identifies the "import-export" pattern of production activity, the rationale for which will be described in the theoretical framework described below.

In this context, the present study assesses the relative importance of using the Grubel and Lloyd (GL) index to reveal behavioural trends in FDI for four Latin American countries (Argentina, Brazil, Chile and Mexico) between 1995 and 2016.

Calculation of the GL index to the four countries reveals their modest share of total "exports" of productive capital (FDI). Moreover, in the cases of Argentina and Brazil, inflows fluctuate widely, so the GL index suggests a degree of production internationalization that is erratic and much lower than that recorded by developed countries and China, which is the developing country bloc used for comparisons in this group. In contrast, Chile and Mexico both have a much higher GL index than Argentina and Brazil, thus displaying greater openness than these two countries but less than the developed countries and China.

Section II of this study discusses the relationship between FDI and international political economy; and it evaluates the flows and stocks of the capital in question, from the standpoint of both host countries (inward FDI) and origin countries (outward FDI). Section III describes the methodology applied in the research using the GL index. Section IV applies the index to the inward and outward FDI of four countries: Argentina, Brazil, Chile and Mexico. The choice of countries is justified by the prominence of their economies relative to other countries in terms of inward FDI, as the sample includes the four leading FDI recipients in Latin America. Lastly, section $V$ presents concluding remarks.

1 This group comprises the following countries: South Africa, Brazil, China, India, Malaysia, Philippines, Mexico, Thailand, and Turkey. 


\section{International political economy and global FDI flows}

The conditions of the international system show that the end of bipolarity and the growth of trade and financial relations have ushered in a new phase of international relations. Despite claims to the contrary, these continue to be largely supported by the State, especially in the central or developed countries. However, the degree of complexity and interdependence of international political and economic relations, stemming from the global interconnection of the production activities of multinational firms, makes this reality different in each case.

In general, there are no major disagreements in the analyses of these transformations when assessing the growth of economic, cultural and social flows, because the fact that societies are increasingly interrelated is a matter of broad consensus. There is also a convergence of ideas regarding the importance of the use of new information technologies that enable interactions to occur at an increasing speed and scale, thereby contributing to a shrinking of real spaces between the different spheres and actors in the international scenario. A large segment of the social sciences assumes that a broad-based process of global interconnection based on material, normative and symbolic relations has prevailed.

What is invariably perceived in discussions of globalization are points of view that approve or disapprove of this process; and an extensive body of analysis has been produced that either criticizes or supports it, and, thus, refutes and/or maintains this reality. To some extent, positions on globalization are divided between sceptics and globalists.

However, beyond the traditional globalist and sceptic division of the theoretical debate on globalization, there is a third alternative, referred to as transformationalist, which seeks to merge elements present in the two extreme positions and offer an analytical proposal that is more reflective of the real complexity of the international system.

Martell (2007) argues that transformationalism seeks to criticize the hyperglobalists, based on the reality that globalization is an inexorable truth. Accordingly, its thoughts on this process find many points of connection with the sceptic perspective.

However, starting from the premise that the importance of liberal policies cannot be underestimated, the transformationists claim that analysis of the current international system should take account of the fact that, despite maintaining a relative centrality in the core country triad, the integration of the global economy has spread beyond this group to countries such as China and Brazil in particular.

On this point, Hay and Marsh (2000) provide a critical review of some of the sceptic positions, noting that their conceptions are often somewhat exaggerated. They therefore propose a multidimensional approach to the globalization process, which develops in a complex and uneven manner. Thus, globalization would not be seen as a process with an end state, but as a trend against which a series of countertrends emerge.

For example, the territorial aspects of the international reality are still considered central to the dynamics of the system, but the idea of this being the basis of modern life is disputed. Economic, social and political issues, while linked to a territory, are also part of a process of de-territorialization. As an example of this, the activities of multinational firms, while maintaining territorial ties, are increasingly seeking new trade and production bases beyond their national borders. According to Martell (2007), a related issue concerns the exclusively quantitative perspective of the analysis of reality as seen by sceptics. Yet, understanding the current stage of globalization also entails evaluating qualitative evidence, through an analysis that considers the individualized and interpretative nature of the whole process. 
In practice, this means that it is not enough to quantify the value of goods and capital traded, or the number of people moving internationally; but, above all, it is essential to assess the qualitative impact of migration, trade and financial flows on the economy, politics and culture of each country through time.

From this perspective, globalization implies new patterns of stratification between and within societies, so that new configurations arise from patterns other than those of the traditional "centre-periphery" dichotomy, since islands of excellence - technological, financial and production sectors - are developing in a number of emerging countries, particularly in Asia and Latin America.

These relationships should be assessed by considering the different ways in which the flow of economic power can be transmitted, especially in terms of the creation of a space continuum, the expansion of trade relations, increased international liquidity, larger flows of factors of production and information, and the intertwining of cultural issues, among others.

These considerations also raise the need to rethink the role of territorial entities (States or regional power blocs), but from a logic that is convergent with purely capitalist interests.

This seems to be a central point for understanding the main analytical focus of this research, namely FDI flows in Brazil and other selected countries, since it highlights a relationship between capital and the domestic political decisions of a country at a time when the flow of capital has grown significantly in the last twenty years.

In this regard, the functional integration of multinational firms has been fundamental in characterizing the current context of globalization, which is increasingly based on a production chain that interconnects a sequence of operational functions, in which each stage adds value to the process of producing goods and services. In turn, this production chain raises the need to understand two important questions: how it is coordinated and regulated, and its geographical configuration.

With regard to the first point, the production chains established by multinational firms are characterized by their power to coordinate and control operations in more than one country and have developed increasingly sophisticated mechanisms of intra- and inter-organizational relations, shaping the contours of the current economic system.

On the other hand, all business organizations, including the most global multinationals, operate within some kind of regulatory system, since they are subject to national laws, even if they try to act with the clear objective of taking advantage of these regulations.

The result of this relationship, as Strange (1979) notes, is an expansion of the complexity of the relationships involved in business decisions, establishing a games logic between firms and States basically configured in a triangular interaction: firm-firm, State-State and firm-State. This configuration of reality, according to Dicken (1998), is responsible for a new "geo-economics", which is in a constant restructuring process and is produced by the actions of both firms and States, forming a tangle of dynamic relationships.

Accordingly, investment decisions, as expressed in recent trends in FDI flows, show that national borders continue to constitute the real differences in global economic policy, as they are one of the main determinants of firms' location choices, conditions that directly influence the flow of this capital.

Consequently, States have increasingly sought to act in the international system to influence the geographic choices of multinational firms. The main expressions of this process are the conditions offered to transnational corporations on access to the domestic market and factors of production.

Multinational firms can establish themselves by implementing new processes and production plants, but they can also do so through mergers and acquisitions. In this connection, it is worth assessing whether FDI flows have in fact enabled the economic restructuring of many developing countries, which may involve improving the productivity of some of their activities. 
The price a country pays for participating in this game depends on the number of independent foreign firms competing for the investment opportunity, the importance for the country of the multinational firm to be established and the perceived level of national need for such a contribution.

Multinational firms, in turn, tend to base their decisions on the attractiveness of the specific investment opportunity offered by the host country in exchange for similar opportunities found in other countries; the economic conditions of the host country, especially its market position; and its degree of political stability.

Thus, it is concluded that the main components of the bargaining relationship between multinational firms and host countries are based on their power resources. Moreover, both operate under certain conditionalities that tend to restrict the scope of the exercise of these resources.

This expansion of capital flows in the international economic system largely speaks to the false notion that FDI has become preferable to portfolio investment and bank loans. In general, this view that FDI is not subject to the vagaries of other types of financial capital stems partly from examples drawn from the development models of Asian countries in the 1990s, which are known to have been closely linked to FDI.

One of the main arguments used to spread the idea that attracting FDI is the most appropriate form of financing is to associate it with fixed capital investments, which do not have immediate liquidity, unlike investments in public or private portfolios.

However, for Kregel (1996), such distinctions do not pertain to developing countries today; so, this capital should not necessarily be evaluated from a long-term perspective. This is because the intensity and importance of merger and acquisition processes dominated by developed countries is generally ignored. In this perspective, the author considers that innovation in financial markets turns the capital of many firms into a real commodity that is traded on a daily basis.

In addition to this, innovations in the international financial market have enabled the development of hedging methods, including FDI transactions in fixed assets, so that an operation may not directly involve the investor in actions affecting the exchange rate, nor even in transactions involving the capital market.

It is in this context that Brazil and, according to this research, the other selected countries, have consolidated themselves as actors with a degree of protagonism in the international system. The first objective of these actors is to express themselves as leaders among developing countries; and a second one is to open a prominent space for participation in the context of globalization.

Since the main objective of this research is to analyse the flow of capital to Argentina, Brazil, Chile and Mexico, through the Grubel-Lloyd (GL) index between 1995 and 2016, this study uses the concept of FDI defined by the United Nations Conference on Trade and Development (UNCTAD) (UNCTAD, 2020), which characterizes these investments as operations aimed at contracting a lasting business in the country of origin of the holder of such capital. Thus, FDI requires the existence of a headquarters and a subsidiary outside the headquarters, which leads to their joint operation, making it a multinational enterprise. It also requires a relationship of total control of the headquarters over the subsidiary outside the border to which the capital belongs; this control is expressed by the ownership of at least $10 \%$ of a corporation's common shares or voting rights, or its equivalent for private firms.

Having established this definition, FDI flows in terms of the amounts internalized by the countries receiving this capital, grew intensively in the 1990s. The trend has tended to grow uninterruptedly even through the international economic crises of the early 2000s and the 2008 crisis. One year before the 2008 crisis, the total flow of FDI absorbed by the various host countries was around US $\$ 2$ trillion (in current prices). In this new crisis context, the flows behaved erratically, leading to a decrease in global flows, compared to 2007, as shown in figure 1. 
Figure 1

Global foreign direct investment inflows, 1970-2016

(Billions of dollars at current prices)

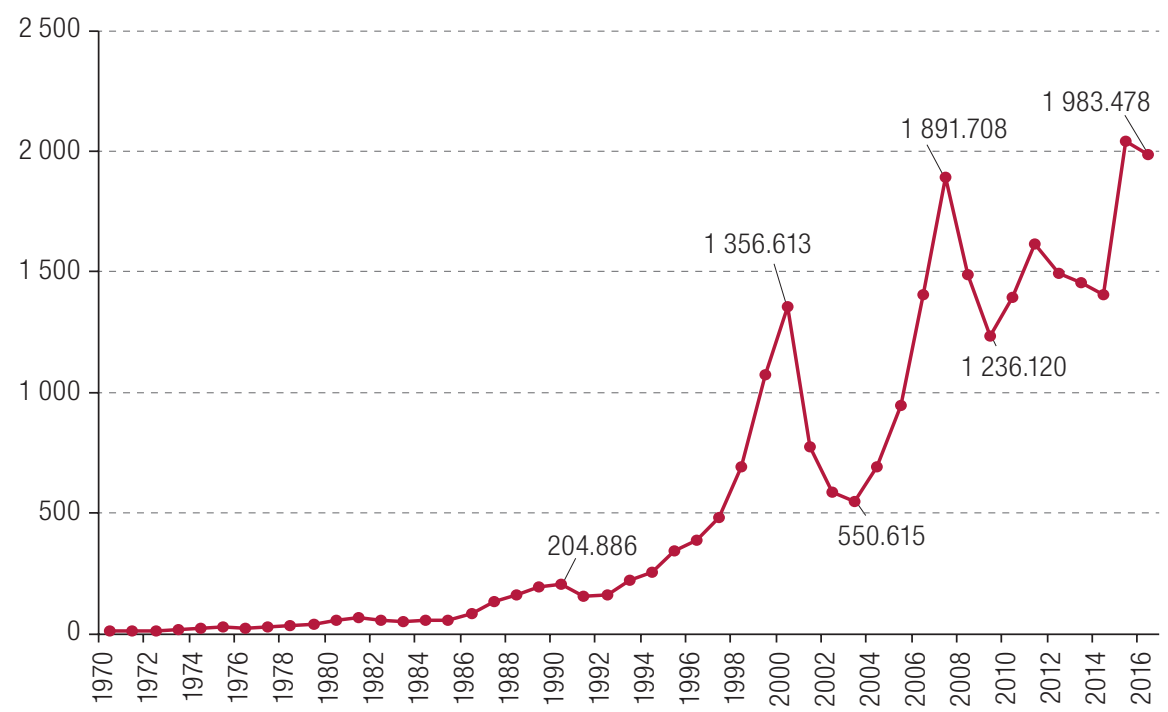

Source: United Nations Conference on Trade and Development (UNCTAD).

An analysis of these flows from host countries during the period of this study (1995-2016) shows that developed countries received $59.7 \%$ of global FDI, with developing countries absorbing $36.6 \%$, and the "transition countries" $3.6 \%$. In addition to the evidence of the predominance of developed countries as the destination of this capital, the United States economy alone received $16.9 \%$ of the total flow in the period in question.

Table 1

Selected countries and groupings:

foreign direct investment inflows, total between 1995 and 2016

(Billions of dollars at current prices)

\begin{tabular}{llrr}
\hline Ranking & Countries & Billions of dollars & Percentage of total \\
\hline \multirow{2}{*}{} & Total & 24785.947 & 100.00 \\
\cline { 2 - 4 } & Developed economies & 14801.062 & 59.72 \\
\cline { 2 - 4 } & Developing economies & 9069.407 & 36.59 \\
\cline { 2 - 4 } & Transition economies & 910.920 & 3.68 \\
\cline { 2 - 4 } & Latin America and the Caribbean & 2328.583 & 9.39 \\
\hline $1^{\circ}$ & United States & 4188.608 & 16.9 \\
\hline $2^{\circ}$ & China & 1778.229 & 7.2 \\
\hline $3^{\circ}$ & United Kingdom & 1716.856 & 6.9 \\
\hline $4^{\circ}$ & China, Hong Kong SAR & 1156.861 & 4.7 \\
\hline $5^{\circ}$ & Belgium & 887.680 & 3.6 \\
\hline $6^{\circ}$ & Germany & 850.854 & 3.4 \\
\hline $7^{\circ}$ & Brazil & 836.311 & 3.4 \\
\hline $8^{\circ}$ & Netherlands & 810.011 & 3.2 \\
\hline $9^{\circ}$ & Canada & 803.538 & 2.9 \\
\hline $10^{\circ}$ & Singapore & 714.095 & 2.1 \\
\hline $16^{\circ}$ & Mexico & 508.987 & 1.0 \\
\hline $24^{\circ}$ & Chile & 237.432 & 0.7 \\
\hline $31^{\circ}$ & Argentina & 174.413 & \\
\hline
\end{tabular}

Source: United Nations Conference on Trade and Development (UNCTAD). 
Apart from China, Brazil is the developing country that received the most FDI $-2.7 \%$ of the total between 1995 and 2016 for a total amount of US\$836.3 billion. The other countries studied in this article - Mexico, Chile and Argentina - have shares and amounts received as shown in table 1. It should also be noted that the four countries in the sample (Argentina, Brazil, Chile and Mexico) account for $75.5 \%$ of the total flow absorbed by Latin American and Caribbean countries during the period analysed.

An analysis of FDI flows in terms of origin shows that $78.4 \%$ of the capital comes from developed countries, while 19.2\% comes from developing ones and 2.4\% from countries in transition.

The main FDI "exporter" is the United States, which provides nearly one fifth of the total amount. The United States is followed by the major economies of Europe, as well as Japan, Hong Kong and Canada.

Brazil, despite being among the largest economies in the world, sends a relatively small share of FDI to other countries, as also is true of Mexico, Chile and Argentina; these countries generated 1.5\% of total outward FDI, and $76.6 \%$ of the total sent by the countries of Latin America and the Caribbean in the period analysed, as shown in table 2.

Table 2

Selected countries and groupings:

foreign direct investment outflows, total between 1995 and 2016

(Billions of dollars at current prices)

\begin{tabular}{llrc}
\hline Ranking & Countries & Billions of dollars & Percentage of total \\
\hline \multirow{2}{*}{} & Total & 24017.089 & 100.00 \\
\cline { 2 - 4 } & Developed economies & 18827.930 & 78.39 \\
\cline { 2 - 4 } & Developing economies & 4605.962 & 19.18 \\
\cline { 2 - 4 } & Transition economies & 575.905 & 2.40 \\
\cline { 2 - 4 } & Latin America & 469.802 & 1.96 \\
\hline $1^{\circ}$ & United States & 4859.109 & 20.2 \\
\hline $2^{\circ}$ & United Kingdom & 1669.128 & 6.9 \\
\hline $3^{\circ}$ & Germany & 1506.727 & 6.3 \\
\hline $4^{\circ}$ & Japan & 1478.278 & 6.2 \\
\hline $5^{\circ}$ & Netherlands & 1323.072 & 5.5 \\
\hline $6^{\circ}$ & France & 1303.535 & 5.4 \\
\hline $7^{\circ}$ & Hong Kong & 1104.116 & 4.6 \\
\hline $8^{\circ}$ & China & 971.487 & 4.0 \\
\hline $9^{\circ}$ & Canada & 924.251 & 3.8 \\
\hline $10^{\circ}$ & Spain & 885.227 & 3.7 \\
\hline 31 & Mexico & 123.055 & 0.5 \\
\hline 32 & Chile & 121.941 & 0.5 \\
\hline $35^{\circ}$ & Brazil & 86.536 & 0.4 \\
\hline $50^{\circ}$ & Argentina & 28.128 & 0.1 \\
\hline
\end{tabular}

Source: United Nations Conference on Trade and Development (UNCTAD).

When comparing the FDI flows received by the four countries in the sample with the size of their economies, Chile's inward FDI/GDP ratio was much higher than that of the other economies analysed (Argentina, Brazil and Mexico), as well as being significantly higher than the same ratio recorded for the group of developing countries.

While this indicator for Argentina, Brazil and Mexico averaged 1.9\%, 2.9\% and 2.6\%, respectively, and for developing countries 3.2\%, the FDI inflow/GDP ratio for Chile was 7.6\% on average in 2007-2016, as shown in figure 2 . 


\section{Figure 2}

Selected countries: FDI inflows as a percentage of GDP, 2007-2016 (Percentages)

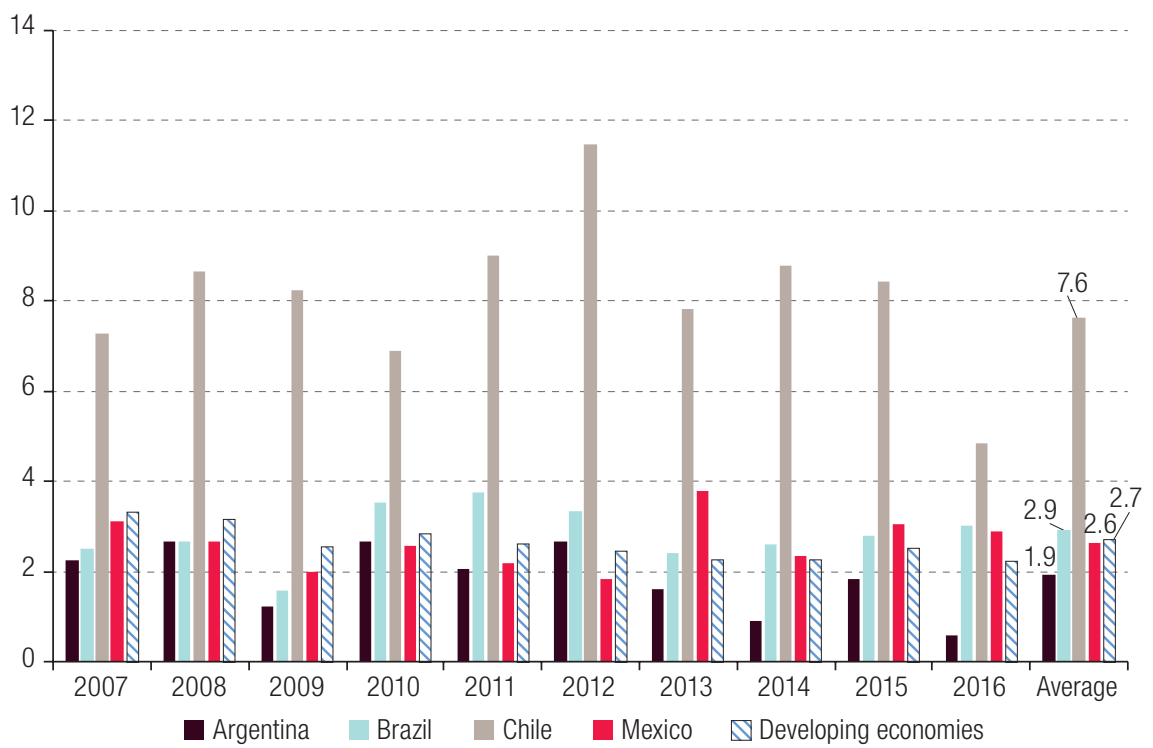

Source: United Nations Conference on Trade and Development (UNCTAD).

Similar behaviour can be seen in FDI outflows for the sample countries, with Chile also displaying a much higher outward FDI/GDP ratio than Argentina, Brazil, Mexico and the developing countries, as shown in figure 3.

Figure 3

Selected countries: FDI outflows as a percentage of GDP, 2007-2016 (Percentages)

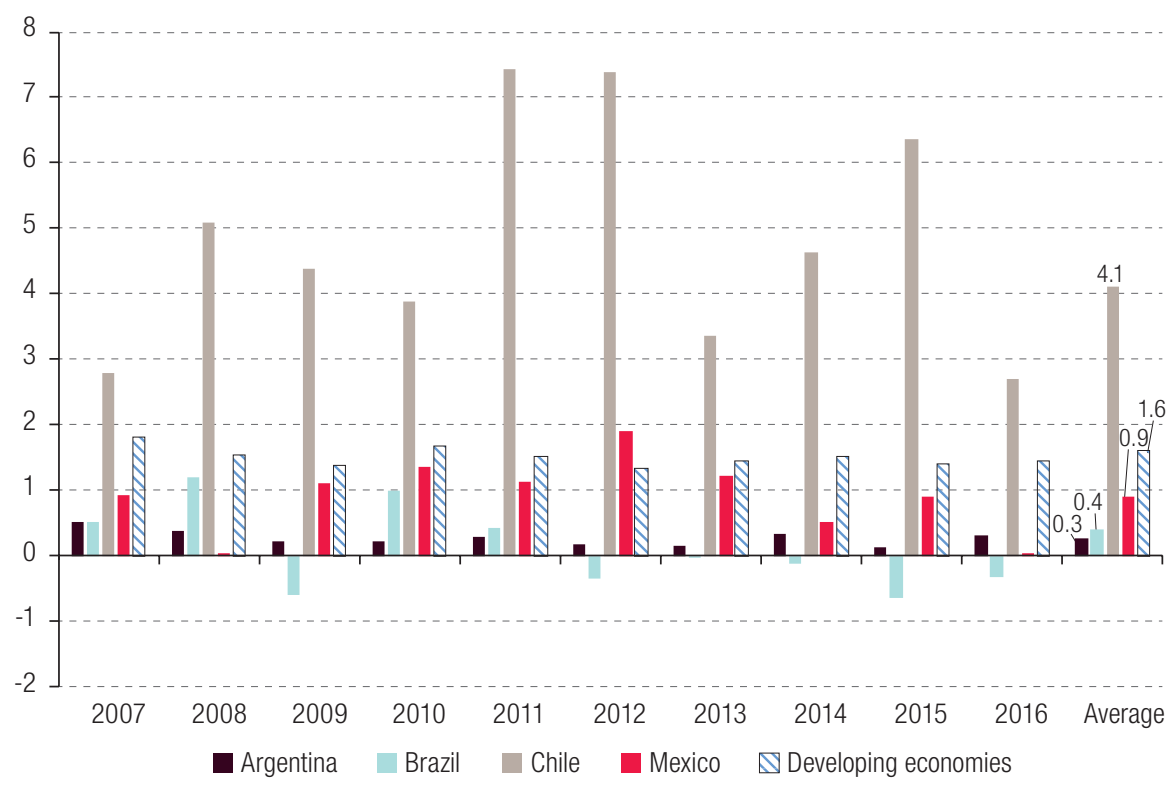

Source: United Nations Conference on Trade and Development (UNCTAD). 
The share of FDI varies from one country to another, both among the ten largest FDI recipient countries and for the four countries in the sample. The importance of foreign firms in Hong Kong's economy is clearly shown by its FDI stock/GDP ratio of above 4. The United States displays a ratio similar to that identified for the group of developed countries, which in turn is also close to the same measure for developing countries.

In the four countries of the sample, Chile's FDI stock represents almost 101.1\% of GDP, showing the major importance of foreign capital for its economic activity, while the equivalent figures in the other countries are: Brazil 39.2\%, Mexico 44.0\% and Argentina 13\%, as shown in table 3.

Table 3

Selected countries and groupings: stock of foreign direct investment relative to GDP, 2016 (Percentages)

\begin{tabular}{llc}
\hline Ranking & Countries & FDI/GDP \\
\hline- & World & 36.1 \\
\hline- & Developing economies & 31.7 \\
\hline- & Developed economies & 39.6 \\
\hline- & Transition economies & 42.1 \\
\hline $1^{\circ}$ & Latin America and the Caribbean & 40.5 \\
\hline $2^{\circ}$ & United States & 35.0 \\
\hline $3^{\circ}$ & China & 12.1 \\
\hline $4^{\circ}$ & United Kingdom & 55.7 \\
\hline $5^{\circ}$ & Hong Kong & 506.68 \\
\hline $6^{\circ}$ & Belgium & 106.9 \\
\hline $7^{0}$ & Germany & 22.6 \\
\hline $8^{\circ}$ & Brazil & 39.2 \\
\hline $9^{\circ}$ & Netherlands & 107.1 \\
\hline $10^{\circ}$ & Canada & 63.68 \\
\hline $16^{\circ}$ & Singapore & 378.3 \\
\hline $24^{\circ}$ & Mexico & 44.0 \\
\hline $31^{\circ}$ & Chile & 101.1 \\
\hline & Argentina & 13.0 \\
\hline
\end{tabular}

Source: United Nations Conference on Trade and Development (UNCTAD).

In the rest of this article, the economic growth of the ten largest FDI recipients and the four sample countries (Argentina, Brazil, Chile and Mexico) will be briefly analysed using the Gl index.

The intention is not to infer any relation between FDI flows and economic activity in these countries, but simply to make a concise descriptive analysis of the change in their real GDPs.

As is well known, China, the third largest recipient of FDI during the period analysed, has posted economic growth rates well above the world average. However, it is impossible to infer the importance of FDI to Chinese economic activity through this simple assessment; the mere fact that the country is a major recipient of this type of capital does not prove that the entry of foreign multinational firms into the country must be a major contributing component.

When the growth of the other main recipient countries is evaluated, the behaviour of their economic activity is similar to the world average.

In the four countries of the sample, Chile is again the standout case, with an economic growth rate well above that of the other countries, and also above the world average. In this regard, it is worth noting the importance of FDI in the Chilean economy, at nearly $60 \%$ of GDP.

Brazil and Argentina also posted real GDP growth rates above the world average, whereas growth in Mexico underperfomed. Table 4 presents additional details. 
Table 4

Top ten FDI recipients and other selected countries: cumulative and average economic growth, 1995-2016

(Percentages)

\begin{tabular}{llrc}
\hline Ranking of FDI inflows & Countries & $\begin{array}{c}\text { Cumulative variation } \\
\text { of real GDP (\%) }\end{array}$ & $\begin{array}{c}\text { Average real GDP } \\
\text { growth, 1995-2016 (\%) }\end{array}$ \\
\hline- & World & 88.94 & 2.93 \\
\hline $1^{\circ}$ & United States & 70.29 & 2.45 \\
\hline $2^{\circ}$ & China & 630.35 & 9.46 \\
\hline $3^{\circ}$ & United Kingdom & 63.31 & 2.25 \\
\hline $4^{\circ}$ & China, Hong Kong SAR & 113.14 & 3.50 \\
\hline $5^{\circ}$ & Belgium & 55.21 & 2.02 \\
\hline $6^{\circ}$ & Germany & 43.55 & 1.66 \\
\hline $7^{\circ}$ & Brazil & 78.95 & 2.68 \\
\hline $8^{\circ}$ & Netherlands & 66.82 & 2.35 \\
\hline $9^{\circ}$ & Canada & 84.98 & 2.84 \\
\hline $10^{\circ}$ & Singapore & 239.63 & 5.72 \\
\hline $16^{\circ}$ & Mexico & 85.12 & 2.84 \\
\hline $24^{\circ}$ & Chile & 180.13 & 4.79 \\
\hline $31^{\circ}$ & Argentina & 82.96 & 2.78 \\
\hline
\end{tabular}

Source: World Bank.

Having described recent FDI flows in the world and, in particular, in Argentina, Brazil, Chile and Mexico, the following sections will seek to broaden understanding of this topic based on the methodological discussion and calculation of the GL index for the four economies in question and for the group of developed countries.

The index in question represents a methodological alternative with potential to provide a new interpretation of these capital movements, noting that the results show a trend specific to the group of developing countries. In addition to the other characteristics already described throughout this section, this can contribute to the debate on FDI from the international political economy standpoint developed here.

\section{The Grubel-Lloyd Index}

The Grubel-Lloyd (GL) index became popular in the late 1970s, with research into the determinants of trade patterns between countries. This followed numerous attempts to explain these determinants both theoretically and empirically, ranging from the Ricardian model to modern theories of international trade that consider imperfectly competitive markets and the emergence of economies of scale as an important driver of trade. Ricardo's theory of comparative advantage showed that a country should specialize in the production of goods that involve a relatively lower opportunity cost than other countries. This important explanation was complemented by the Heckscher-Ohlin-Samuelson model, according to which a country has comparative advantages in goods whose production makes intensive use of a factor of production that is abundant in the country. The findings of the Ricardian and Heckscher-Ohlin-Samuelson models imply that countries trade in different products in international trade.

In more recent models, such as those of Krugman (1979 and 1980), an additional factor emerges as an important determinant of the pattern of trade between countries. Product differentiation, a characteristic of imperfectly competitive markets, explains why different countries trade similar products. Previous models did not allow for this possibility. The presence of economies of scale, combined with the product differentiation characteristic of imperfectly competitive markets was not present in traditional trade models and accounts for a substantial part of a country's trade with the rest of the world. In other 
words, while the comparative advantage theory and the Heckscher-Ohlin-Samuelson model explain why a country exports agricultural products and imports manufactured products, the product differentiation thesis explains how two countries trade in the same type of product, such as automobiles.

International trade can be seen as consisting of two parts: inter-industry trade and intra-industry trade. The former refers to the pattern of trade explained by comparative advantages and the factor-proportion model. In contrast, intra-industry trade is due to the existence of imperfect markets, which is an important source of gains to trade, insofar as it allows for scale gains in differentiated products.

Inter-industry trade is thus determined by the abundance of one or more factors of production in a country. Capital-abundant countries tend to export capital-intensive products, such as technology and medicines. Conversely, land-abundant countries tend to export mainly agricultural products. Unlike inter-industry trade, intra-industry trade is unpredictable, although it is possible to identify a number of factors that contribute to its emergence. One relevant fact concerns the underlying characteristics of the countries in question. For example, if two countries have identical factor shares, there will be no inter-industry trade between them. Instead, there will likely be intra-industry trade, since economies of scale are an important source of trade benefits.

To calculate intra-industry trade, one of the most widely used indices is that of Grubel and Lloyd (1975), which has frequently been applied in international trade studies, mainly during the 1980s and is presented in the recent literature in the following format:

$$
G L I_{I T}=\frac{\sum_{i=1}^{n}\left(x_{i}+m_{i}\right)-\sum_{i=1}^{n}\left|x_{i}-m_{i}\right|}{\sum_{i=1}^{n}\left(x_{i}+m_{i}\right)} \text { in which } 0 \leq G L I_{I T} \leq 1
$$

where:

$G L I_{I T}=$ index of intra-industry trade in the sector

$x_{i}=$ exports of the product or sector

$m_{i}=$ imports of the product or sector

The original Grubel-Lloyd equation is expressed as the result of equation (1) multiplied by 100, which means the result will always be in the interval $[1,100]$. However, in recent studies, the factor was removed and the result started to be given in the interval $[0,1]$. Thus, when the value of exports of a given industry is similar to the value of imports, the index result will be close to 1 . In contrast, the greater the difference in value between exports and imports, the closer the index result will be to 0 . A result close to 0 indicates the existence of inter-industry trade, based, for example, on comparative advantages or abundance of factors of production.

In analysing the possible frontiers of intra-industry trade research, Herbert Grubel, one of the creators of the index, suggested that the GL index could perfectly well be applied to a country's balance of payments (Grubel, 2002). The author argued that international capital flows can be viewed as different "industries", such as portfolio investment, foreign direct investment and loans, and other categories. Using data from the International Monetary Fund, Grubel (2002) calculated GL indices for the financial accounts of Germany's balance of payments.

In addition, Grubel calculated the GL index of the FDI variable for several developed countries and also for regions. The author also conducted an analysis of other balance of payments "industries" such as portfolio investment and loans. The study concluded that there is significant intra-industry trade in assets among developed countries, with emphasis on portfolio investment.

For the present analysis, the GL index defined above was adapted to consider investment flows, according to the following expression: 


$$
G L I_{F D I}=\frac{\left(F D I_{\text {out }}+F D I_{\text {in }}\right)-\left|F D I_{\text {out }}-F D I_{\text {in }}\right|}{\left(F D I_{\text {out }}+F D I_{\text {in }}\right)} \text { in which } 0 \leq G L I_{F D I} \leq 1
$$

where:

$G L I_{F D I}=$ index of "intra-industry" direct investment

$F D I_{\text {out }}=$ outward foreign direct investment

$F D I_{\text {in }}=$ inward foreign direct investment

The adapted GL index makes it possible to calculate FDI inflows and outflows and to understand the dynamics of flows or stocks for a given economy. The result of equation (2) will always be in the interval $[0,1]$. When the flow is only, or predominantly, in one direction, the result of the calculation will be close to 0 . In contrast, the closer the inward and outward FDI values are to each other, the closer the result of the equation will be to 1 .

The index has a number of limitations, however. If a country's FDI flows are predominantly inward or outward, the index will be the same, close to 0 , regardless of direction. Moreover, if a country has both inflows and outflows of similar values in a given year, the index will remain close to 1. Since this is a relative index, it should be interpreted with caution. Nonetheless, the application of the GL index can be useful in comparisons and analysis of FDI flows, among other issues.

The suggestion for this calculation, with applications, appeared in Grubel (2002); and other studies subsequently applied the GL index to FDI flows and other variables. For example, Obstfeld (2004) applied the index to international asset flows, to assess potential imbalances in the indebtedness of some countries. However, that author qualified the index as a two-way asset trade index rather than an index of intra-industry trade in assets. Grubel (2002) noted that economists have suggested the work published as intra-industry trade in assets should be renamed as two-way asset trade. Although Obstfeld's (2004) view is more theoretically consistent, the present study maintains Grubel's taxonomy. Other studies applying the GL index to assets include Lane and Milesi-Ferretti (2007) and Obstfeld (2012).

\section{The Grubel-Lloyd index applied to Argentina, Brazil, Chile and Mexico}

With data on the stocks of inward foreign investment (FDI-in) and local investment abroad (FDI-out) obtained from UNCTAD, equation (2) made it possible to calculate the GL index for four selected Latin American countries (Argentina, Brazil, Chile and Mexico). These countries were the main FDI recipients in Latin America for the period analysed, which justifies their selection for the analysis. The analysis uses the same indicator for the group of developed countries as comparator, ${ }^{2}$ in order to reinforce the debate on the movement of this form of capital.

As shown in figure 4, the index for developed countries is relatively stable compared to those of the countries in the sample analysed below; it's level is also fairly high - an average of 0.87 for the period 1995-2016 - when the inflows and outflows are evaluated concurrently, characteristics that are not found for the four countries evaluated.

\footnotetext{
2 According to the classification of the Department of Economic and Social Affairs (DESA) of the United Nations Secretariat. For further details see: http://www.un.org/en/development/desa/policy/wesp/wesp_current/2014wesp_country_classification.pdf.
} 
Figure 4

Developed countries: inward and outward foreign direct investment and Grubel-Lloyd index, 1995-2016

(Billions of dollars)

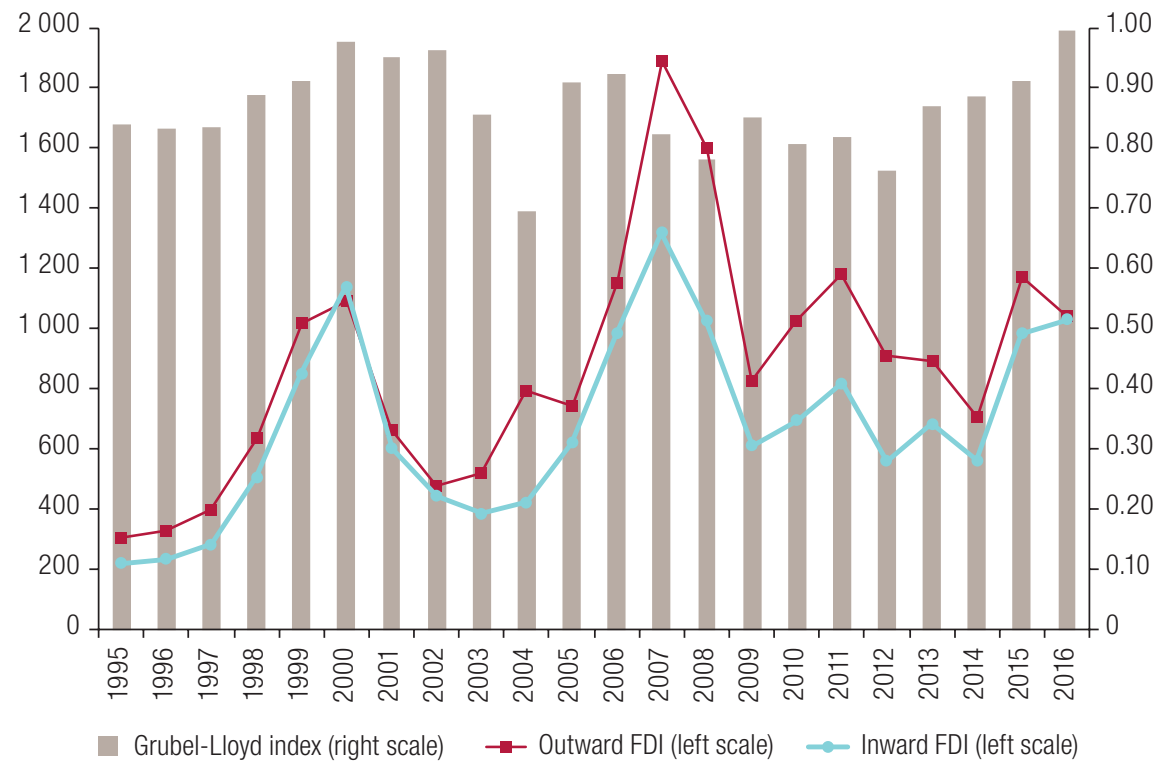

Source: Prepared by the authors on the basis of information from United Nations Conference on Trade and Development (UNCTAD).

The GL index for China was also calculated, not only because of the relative importance of this country in global flows, but also because it belongs to the developing country group, with which comparisons will be made of the results obtained for the four countries (Argentina, Brazil, Chile and Mexico).

China displays atypical behaviour compared to the rest of the developing countries, either because of the amount of investments, both inward and outward, which makes it the second and most important FDI exporter; or because of the behaviour of the calculated GL index, whose growth trend leads to results with the maximum scale of the indicator, in other words close to 1 , since the inflows of such capital have been very close to the outflows, as shown in figure 5. 


\section{Figure 5}

China: inward and outward foreign direct investment and Grubel Lloyd index, 1995-2016

(Billions of dollars)

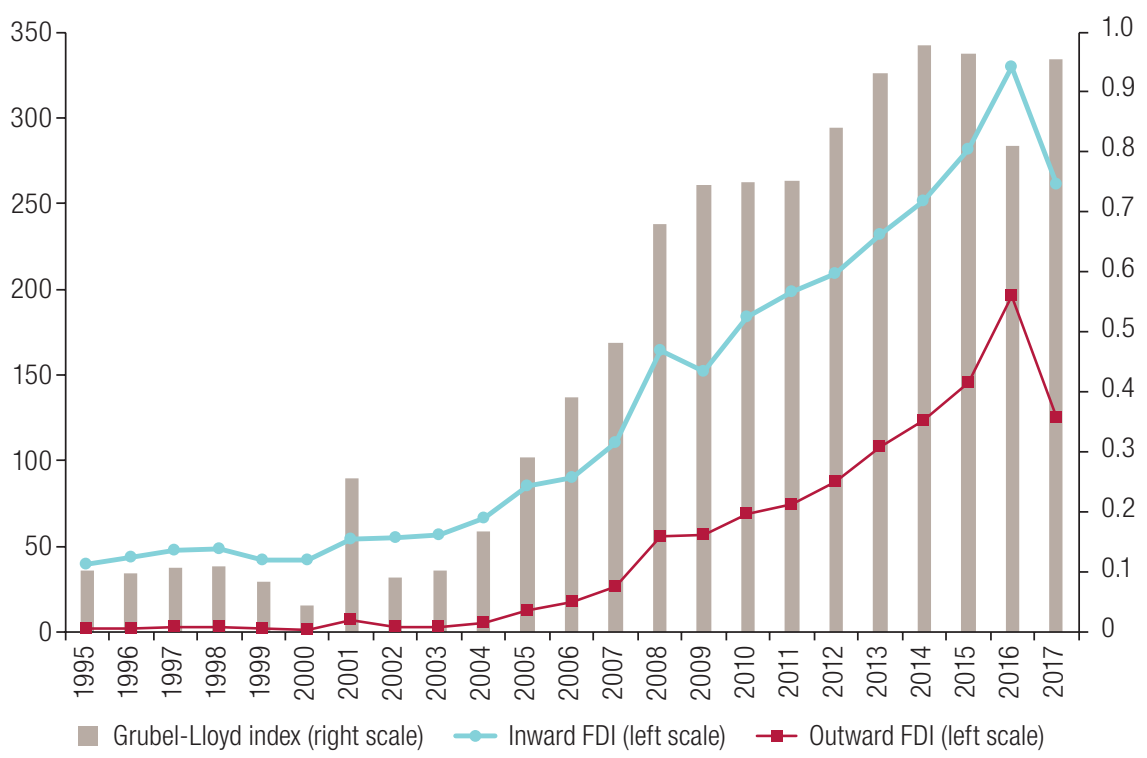

Source: Prepared by the authors on the basis of information from United Nations Conference on Trade and Development (UNCTAD).

\section{Argentina}

The Argentine economy absorbed significant FDI inflows in the 1990s as a consequence of the relative economic stability provided by the currency board regime applied at the start of the decade. In this regard, figure 6 shows an upward trend in FDI inflows until 1999, after which there was an inflection following the currency crisis in Brazil, which affected the Argentine economy.

In the case of outflows, that is investment by Argentines abroad, a similar behaviour pattern is observed in the period analysed, with a net negative outflows in 2002, which means that the country's residents "disinvested" the resources that had been invested abroad previously. The cause of this behaviour can be attributed to the collapse of the currency board regime, which led a process of devaluation and greater instability in the Argentine economy.

Thus, the GL index fluctuated in 1995-2016, while remaining below 0.3 in most of the period, reflecting the discrepancy between FDI inflows and outflows in the country.

These results are explained by the erratic movement of inflows and the small volume of outward FDI. In general, the values of the GL index are well below those calculated for the group of developed countries and for China. This indicates a relatively low degree of internationalization of production for the period analysed, despite the fact that Argentina had achieved a broad economic liberalization in the 1990s.

Confirmation of this is provided by the FDI/GDP ratio, which for Argentina was just $13 \%$ in 2016, well below the equivalent indicators for Latin America as a whole (40.5\%) and the other sample countries, as shown in table 3.

As the share of FDI outflows is very small for the four countries in the sample, the same comparison will not be made for any of them in this study. 
Figure 6

Argentina: inward and outward foreign direct investment and Grubel-Lloyd index, 1995-2016

(Billions of dollars)

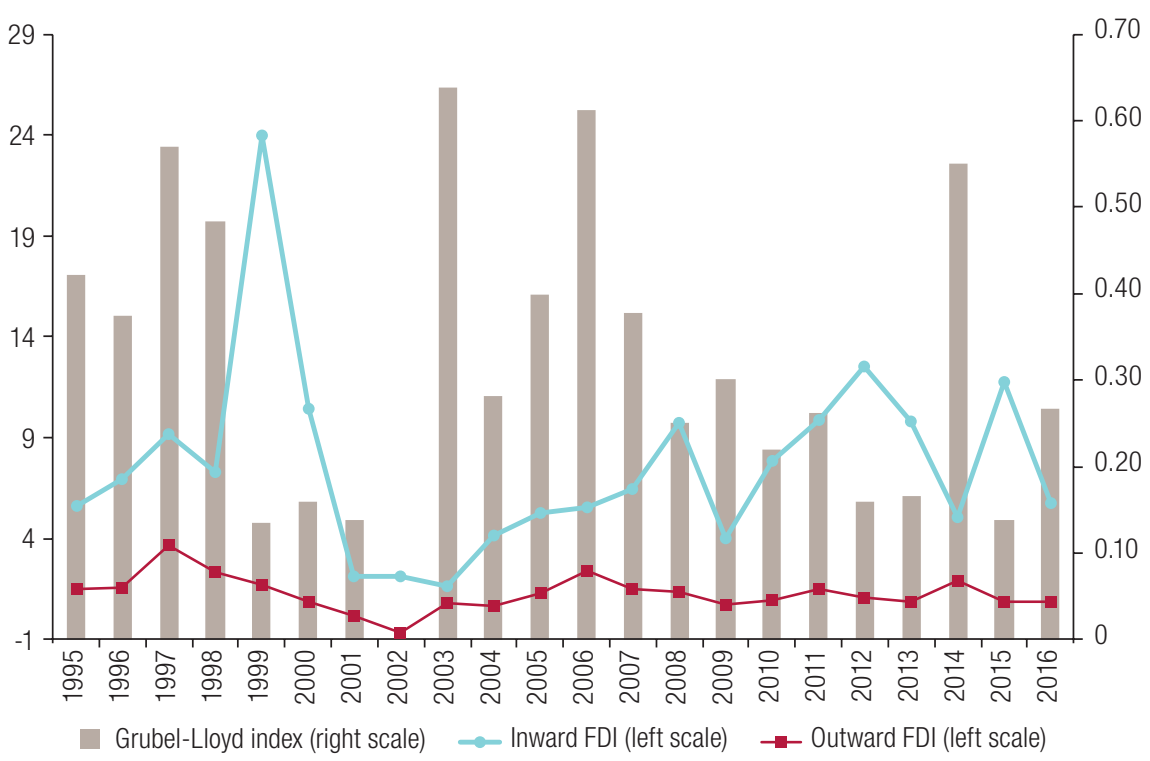

Source: Prepared by the authors on the basis of information from United Nations Conference on Trade and Development (UNCTAD).

\section{Brazil}

The Brazilian economy received significant FDI inflows in different periods of time. The first period (1997-2001) was marked by the process of privatization of State-owned enterprises, while the second (2003-2008) was related to the commodity price boom on international markets and the economic growth with price stability that the Brazilian economy experienced. Following the reduction in inflows during the 2008 international crisis, the growth trajectory resumed in 2011-2016.

Investment by Brazilian residents abroad (FDI-out) has fluctuated but trended up since 2003, albeit interrupted by the 2008 crisis. As a result, FDI flows produced in a GL index above 0.30 in just three years (2004, 2006 and 2008), which reveals a divergent pattern of investment inflows and outflows for the period analysed.

The low level of the index, compared to those of the group of developed countries and China, stems from the large difference between inflows and outflows. Brazil was the world's seventh largest FDI recipient in the period but thirty-seventh among "FDI exporters". In addition, outflows have trended down strongly, as shown in figure 7. 
Figure 7

Brazil: inward and outward foreign direct investment and Grubel-Lloyd index, 1995-2016 (Billions of dollars)

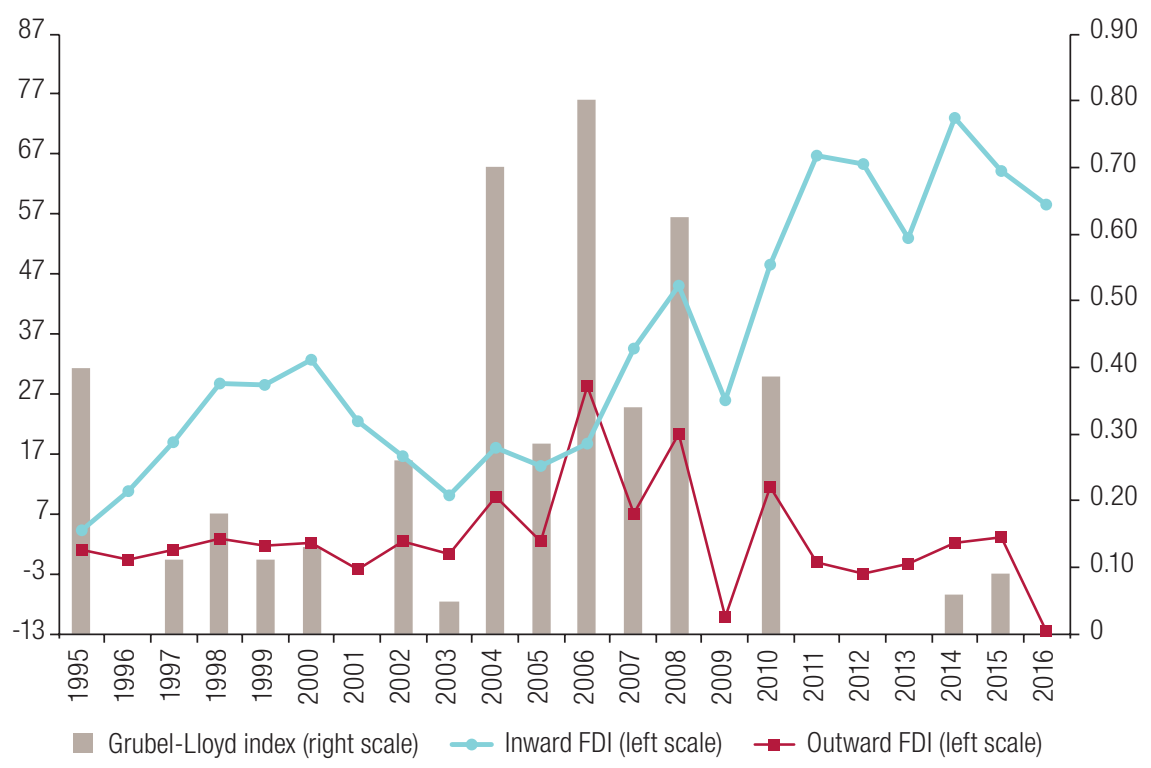

Source: Prepared by the authors on the basis of information from United Nations Conference on Trade and Development (UNCTAD).

\section{Chile}

Most of Chile's inward FDI is channelled into the mining sector, reflecting the importance of copper for the country's economy. Official statistics show that about 35\% of the total stock of foreign investment is in this segment. Excluding data for the undeclared sectors, this represents more than $50 \%$ of the total stock of foreign capital channelled into Chile's production sectors. ${ }^{3}$

In the case of investments by Chilean residents in the rest of the world, mining activity again absorbs for most of the capital, since 45\% of the total stock in 2016 was linked to this sector. The main destinations in that year were Brazil, Argentina, Luxembourg and Spain.

In this regard, figure 8 displays the greater symmetry between FDI inflows and outflows in the Chilean economy. This results in a calculated series in which the GL index is above 0.60 for more than half of the period. In other words. Chile displays a relatively more regular pattern than the other countries when comparing inflows and outflows.

Chile's FDI inflows and outflows also do not display the erratic behaviour of the other countries in the sample until 2012, when both flows drop. Outflows have also behaved similarly to inflows, which explains why its GL index is higher than that calculated for Argentina, Brazil and Mexico.

It is also possible to argue that Chile's openness in the 1970s led to a significant internationalization of its production activity, such that its FDI/GDP ratio is $101.1 \%$, is above the levels reported in both the developed and Latin American blocs, as shown in table 3.

\footnotetext{
${ }^{3}$ According to statistics from the Central Bank of Chile. Available in: https://si3.bcentral.cl/estadisticas/Principal1/Estudios/SE/ BDP/ied.html.
} 
Figure 8

Chile: inward and outward foreign direct investment and Grubel-Lloyd index, 1995-2016 (Billions of dollars)

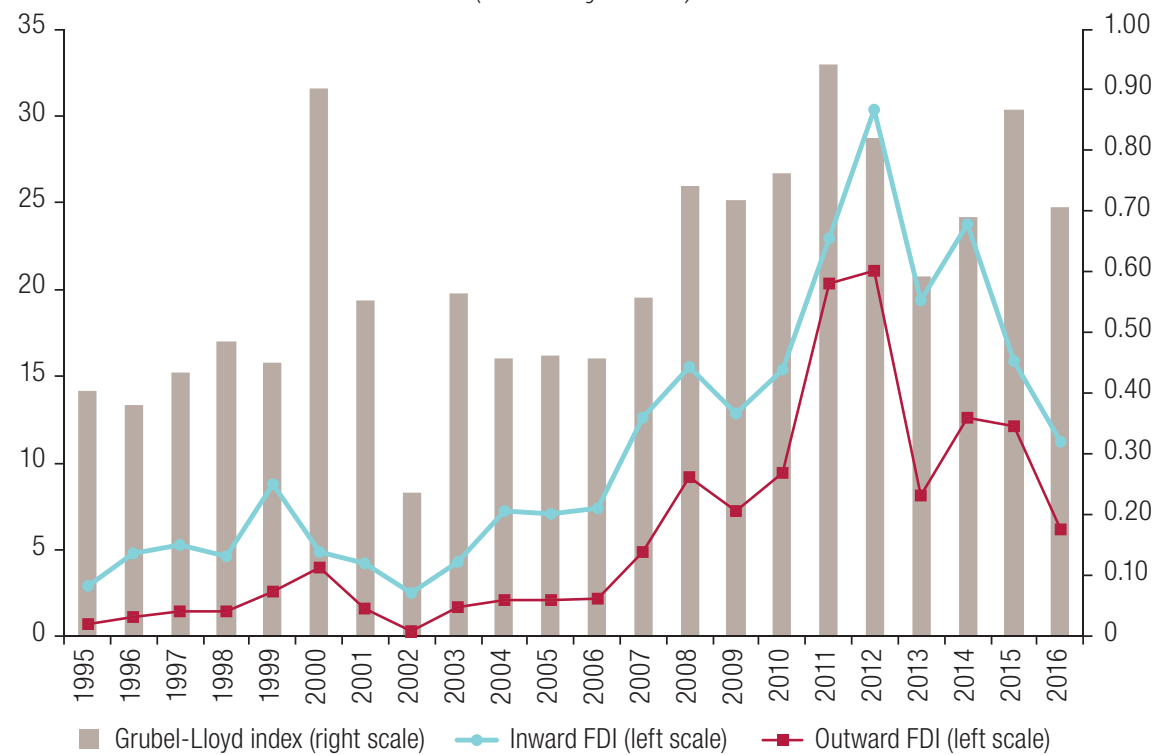

Source: Prepared by the authors on the basis of information from United Nations Conference on Trade and Development (UNCTAD).

\section{Mexico}

The analysis of foreign investment inflows and outflows in the Mexican economy reveals that $50 \%$ of the cumulative FDI flows received between 2000 and 2016 came from the United States, and $74.5 \%$ was channelled to the industrial sector. These data reflect Mexico's well-known strong economic relationship with the United States, in which it serves as a link in the manufacturing production chain, through Mexican maquiladora facilities.

Foreign investment inflows into the Mexican economy faltered after the international financial crisis of 2007-2008. With this reduction and the increase in outflows that began in 2009, Mexico began to display GL indexes above 0.50 (see figure 9). In terms of the degree of internationalization, from the standpoint of inflows, Mexico also has a significant share of foreign capital in its economic activity. Its FDI/GDP ratio of $44 \%$ is higher than the Latin American average (see table 3 ).

The results concur with the finding of Grubel (2002), namely that emerging countries tend to have an index relatively close to 0 until a process of trade and financial openness begins that not only expands inflows but also stimulates a stronger outflows. In the 1990s particularly, Latin American countries, especially the four countries covered by the survey, expanded the process of trade and financial openness, which brought FDI inflows and outflows into closer alignment, as shown in the graphs.

As a result, the GL index moved closer to 1, as has been observed in developed economies and was also predicted by Grubel (2002). Obstfeld (2012) also drew attention to the same behaviour, although the index in this case was applied to the gross international asset and liability position of developed and emerging countries.

However, the rising trend of the GL index for Latin American countries' investment flows observed in this study may not be consolidated, since Argentina, Brazil and Mexico all experienced a fall in the index at the end of the period analysed, owing to a reduction in FDI inflows or outflows. 
Figure 9

Mexico: inward and outward foreign direct investment and Grubel-Lloyd index, 1995-2016

(Billions of dollars)

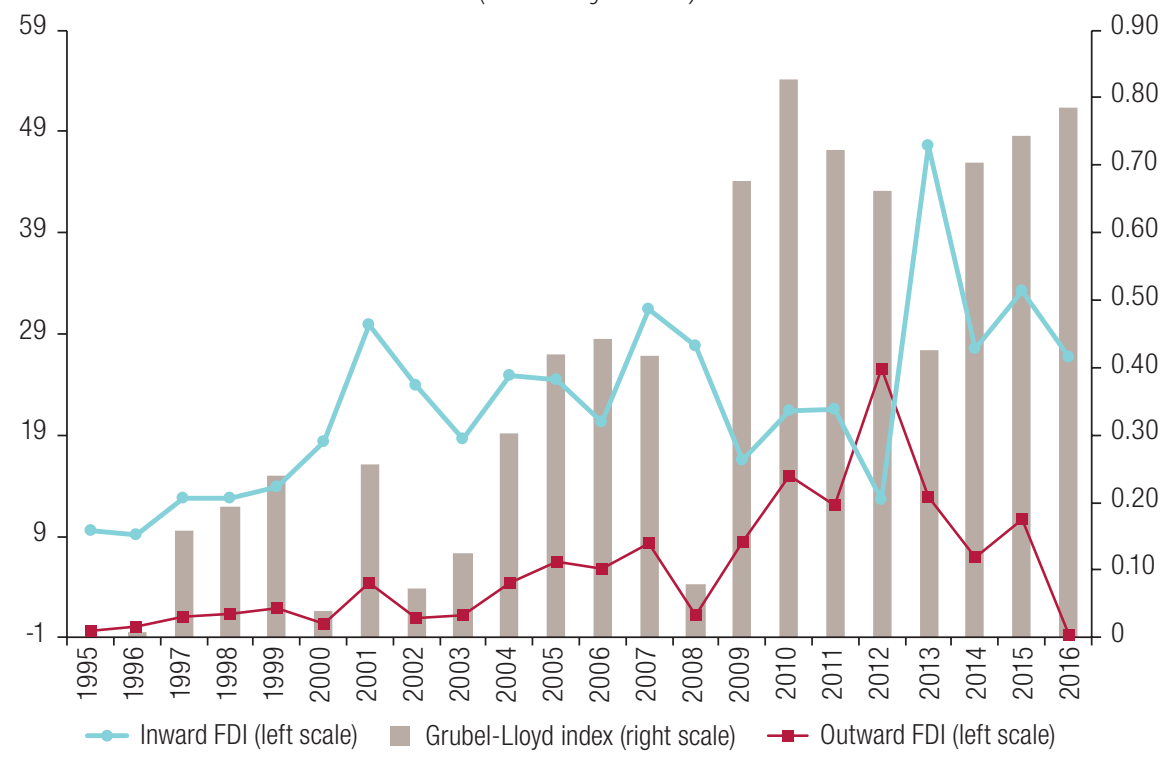

Source: Prepared by the authors on the basis of information from United Nations Conference on Trade and Development (UNCTAD).

\section{Concluding remarks}

This article set out to analyse the behaviour of foreign investment inflows and outflows in four selected Latin American countries (Argentina, Brazil, Chile and Mexico) from 1995 to 2016, through the Grubel and Lloyd index adapted to the behaviour observed in developed countries. As noted throughout the study, the index for developed countries behaves differently from the pattern identified for the countries in the sample, since for the first group the indicator, in addition to being high, is relatively stable; this contrasts sharply with the erratic behaviour of the index for Argentina, Brazil, Chile and Mexico.

The analysis of FDI inflows and outflows for these countries demonstrates the importance of this variable for the region's economy. All of these economies display a rising trend in FDI flows, albeit with fluctuations owing to a series of events, including the global economic crisis of 2008.

However, the information extracted from the application of the GL index to these countries shows that FDI inflows have tended to display this trend but have also diverged sharply from outflows, especially in the case of Argentina.

In general, the GL index allows for a comparative evaluation between the four countries and the bloc of developed countries, showing that, in addition to being quantitatively lower, the indicator does not display the stable behaviour typical of this group. Similarly, in relation to China, whose GL index has risen significantly in the last ten years, the degree of production internationalization of Argentina, Brazil and Mexico is relatively lower, while Chile already has a more internationalized and effective pattern. Thus, as a group of developing countries, with different historical and political perspectives that are reflected in their economic policies and processes of engagement in the international economy, it is difficult to understand the movement of FDI as a regional trend without an analysis of each of the economies that comprise this group of countries and the relationships they establish among themselves. 
Rather than invalidating the use of the GL index as an indicator of trends in the international economy, these results strengthen it, because it reveals aspects of this reality that would not otherwise be visible. So, by identifying the behaviour of FDI in different economies, either as a group or individually, divergences and idiosyncrasies are revealed. Other studies may lead to an additional explanation of the results observed.

\section{Bibliography}

Chesnais, F. (1996), A Mundialização do Capital, Rio de Janeiro, Xamã.

Corazza, G. (2005), "A inserção do Brasil na Globalização Financeira", paper presented at the Congrès International Marx, Paris.

Dicken, P. (1998), Global Shift: Transforming the World Economy, London, Paul Chapman.

Grubel, H. (2002), "Intra-industry trade in assets", Frontiers of Research in Intra-Industry Trade, H. O. Lee and P. Lloyd (eds.), New York, Palgrave Macmillan.

Grubel, H. and P. Lloyd (1975), Intra-Industry Trade: The Theory and Measurement of International Trade in Differentiated Products, Halsted Press.

Hay, C. and D. Marsh (2000), Demystifying Globalization, Palgrave, Basingstoke.

Kregel, J. A. (1996), "Riscos e implicações da globalização financeira para a autonomia de políticas nacionais", Economia e Sociedade, No. 7.

Krugman, P. (1980), "Scale economies, product differentiation and the pattern of trade", American Economic Review, vol. 70.

_ (1979), "Increasing returns, monopolistic competition, and international trade", Journal of International Economics, vol. 9, No. 4.

Lane, P. R. and G. M. Milesi-Ferretti (2007), "A global perspective on external positions", G7 Current Account Imbalances: Sustainability and Adjustment, R. Clarida, National Bureau of Economic Research (NBER), University of Chicago Press.

Martell, L. (2007), "The third wave in globalization theory", International Studies Review, No. 9, vol. 2, Oxford.

Michalet, C. A. (1985), Le Capitalisme Mondial, Paris, Presses Universitaries de France.

Obstfeld, M. (2012), "Financial flows, financial crises, and global imbalances", Journal of International Money and Finance, vol. 31, No. 3. (2004), "External adjustment", Review of World Economics, vol. 140, No. 4.

Strange, S. (1979), "The management of surplus capacity: or how does theory stand up to protectionism 1970s style?", International Organization, vol. 33, No. 3.

UNCTAD (United Nations Conference on Trade and Development) (2020), "Foreign direct investment: Inward and outward flows and stock, annual", UNCTAD Stat [online] https://unctadstat.unctad.org/wds/ TableViewer/tableView.aspx?Reportld=96740. 